\title{
Communication/Comunicação
}

\section{Evaluation of bacterial growth inhibition by mercaptopropionic acid in metallo- $\beta$-lactamase detection on multidrug-resistant Acinetobacter baumannii}

\author{
Avaliação da inibição do crescimento bacteriano pelo ácido mercaptopropiônico na detecção \\ de metalo- $\beta$-lactamases em Acinetobacter baumannii multirresistente
}

\author{
Letícia Eichstaedt Mayer ${ }^{1}$, Rosmari Hörner ${ }^{1}$, Maisa Kräulich Tizotti ${ }^{1}$, Rosiéli Martini ${ }^{1}$, Magda Cristina Souza \\ Marques Roehrs ${ }^{1}$ and Cláudia Barbisan Kempfer ${ }^{1}$
}

\begin{abstract}
Introduction: Metallo- $\beta$-lactamase (MBL) has been reported all over the world. Methods: The inhibitory effect of mercaptopropionic acid (MPA) on bacterial growth was evaluated by comparison between disk diffusion and broth dilution methodology with determination of the minimum inhibitory concentration (MIC) for multidrug-resistant Acinetobacter baumanni strains. Results: MPA significantly inhibited growth of the strains. Conclusions: The use of MPA can affect the results in phenotypic methods of MBL detection.
\end{abstract}

Keywords: Drug resistance. Acinetobacter baumannii. Microbial sensitivity tests.

\section{RESUMO}

Introdução: Metalo- $\beta$-lactamases (MBL) têm sido reportadas em todo o mundo. Métodos: Avaliamos o efeito inibitório do ácido mercaptopropiônico (AMP) sobre o crescimento bacteriano mediante a comparação entre a difusão em disco e a metodologia de diluição em caldo com a determinação da concentração inibitória mínima (CIM) entre cepas multirresistentes de Acinetobacter baumanni. Resultados: O AMP inibiu o crescimento das cepas do presente estudo de maneira significativa. Conclusões: $\mathrm{O}$ uso do AMP pode afetar os resultados dos métodos de detecção fenotípica de MBL.

Palavras-chaves: Resistência a medicamentos. Acinetobacter baumannii. Testes de sensibilidade microbiana.

Metallo- $\beta$-lactamase (MBL) has been reported all over the world and its fast spread has not been accompanied by standardization of a suitable method for phenotypic detection in the laboratory $y^{1,2}$. The proliferation of MBLs-producing strains must be regarded as a potential public health problem because of the limited therapeutic options, increased morbimortality rates and serious concerns in relation to infection control ${ }^{3-5}$. In this context, Acinetobacter baumannii is an opportunistic Gram-negative pathogen with increasing relevance among nosocomial infections ${ }^{1,3,6}$. The phenotypic methods to detect metalloenzyme producers are based on the fact that these enzymes are affected by the removal of zinc from the active site, which can be performed by chelating agents ${ }^{1,2}$, or by alteration of the active site of the enzyme caused by thiol-based compounds ${ }^{7}$, including mercaptopropionic acid (MPA).

1. Laboratório de Bacteriologia, Departamento de Análises Clínicas e Toxicológicas, Centro de Ciências da Saúde, Universidade Federal de Santa Maria, Santa Maria, RS. Address to: Dra. Rosmari Hörner. Rua Conde de Porto Alegre 1413, 97015-110 Santa Maria, RS, Brasil.

Phone/Fax: 5555 3222-5291

e-mail: rosmari.ufsm@gmail.com

Received in 09/11/2010

Accepted in 24/11/2010
Thus, the fact that the metallo- $\beta$-lactamase inhibitor (IMBL) may possess its own inhibitory activity against bacterial growth in phenotypic tests should be taken into account. Depending on the test concentration of the IMBL, interpretation of the test results may be compromised ${ }^{4}$.

In this study, the inhibitory effect of MPA on bacterial growth was evaluated by comparison between disk diffusion and broth dilution methodology with determination of the minimum inhibitory concentration (MIC) for multidrug-resistant (MDR) A. baumanni strains.

A total of 30 MDR A. baumannii isolates were tested. The strains form part of the bacteria collection of the Bacteriology Laboratory, Department of Clinical and Toxicological Analysis, Center for Health Sciences, Federal University of Santa Maria, Santa Maria, Brazil. Pseudomonas aeruginosa ATCC 27853 (MBL-negative control) and P. aeruginosa SPM-1 (MBL-positive control) were included as controls.

The broth microdilution method was developed according to the criteria of the CLSI ${ }^{8}$ but instead of an antimicrobial agent solution, $20 \mu \mathrm{L}$ of MPA was used, which was dispensed into the first well, obtaining a concentration of $0.74 \mathrm{mg} / \mathrm{L}$. Dilutions were condcuted in subsequent wells to obtain the following concentrations: $0.37 \mathrm{mg} / \mathrm{L}$, $0.185 \mathrm{mg} / \mathrm{L}, 0.0925 \mathrm{mg} / \mathrm{L}, 0.0463 \mathrm{mg} / \mathrm{L}, 0.0231 \mathrm{mg} / \mathrm{L}, 0.0116 \mathrm{mg} / \mathrm{L}$, $0.0058 \mathrm{mg} / \mathrm{L}, 0.0029 \mathrm{mg} / \mathrm{L}$ and $0.0014 \mathrm{mg} / \mathrm{L}$.

In order to determine the minimum bactericidal concentration $(\mathrm{MBC})$, strains inhibited in the visual reading of MIC were subcultured in Mueller-Hinton agar and incubated for at least $24 \mathrm{~h}$ in a bacteriological incubator at $35^{\circ} \mathrm{C} \pm 2$.

Evaluation of MPA activity by the disk diffusion method was performed by applying a filter paper disk on a plate of Mueller-Hinton agar, previously inoculated with a bacterial suspension equivalent to the $0.5 \mathrm{McF}$ arland standard. Three microliters $(3 \mu \mathrm{L})$ of MPA (undiluted) were added to the filter paper disk. The diameter of the inhibition zone produced by the MPA in the strains tested was measured after incubation at $35 \pm 2{ }^{\circ} \mathrm{C}$ for $24 \mathrm{~h}$.

The inhibitor effect of MPA on bacterial growth in the strains studied was evaluated according to the size of the inhibition zone. Inhibition ranged from $14 \mathrm{~mm}$ to $28 \mathrm{~mm}$; a halo of $21 \mathrm{~mm}$ was the most frequent $(n=7)(23.3 \%)$. Picão et $\mathrm{l}^{4}$ reported an increase in the size of the inhibitor zones produced by MPA (from 0.3 to $12.4 \mathrm{~mm}$ ).

A minimum inhibitory concentration of $0.0116 \mathrm{mg} / \mathrm{L}(\mathrm{n}=16)$ (53.3\%) was the most frequent. The MBC of most strains was 
$0.0231 \mathrm{mg} / \mathrm{L}(\mathrm{n}=20)(66.7 \%)$. In the majority of the strains tested, the bactericidal effect was observed at a dilution greater than the $\mathrm{MIC}(\mathrm{MIC}=0.0116 \mathrm{mg} / \mathrm{L}$ and $\mathrm{MBC}=0.0231 \mathrm{mg} / \mathrm{L})$.

In conclusion, no assays have been published in the national or international literature using the MIC technique to evaluate the activity of MPA against A. baumannii growth. MPA significantly inhibited bacterial growth in the strains analyzed in this study, which could affect the results when using phenotypic methods of MBL detection. Analysis of the results demonstrated that the use of MPA as a IMBL should be reconsidered. In the case of preliminary results, a larger number of strains will be analyzed.

\section{CONFLICT OF INTEREST}

The authors declare that there are no conflict of interest.

\section{FINANCIAL SUPPORT}

This study was supported by Coordenação de Aperfeiçoamento de Pessoal de Nível Superior (CAPES), Ministry of Education, Brazil, and Fundação de Incentivo a Pesquisa e Eventos (FIPE), Federal University of Santa Maria.

\section{REFERENCES}

1. Cornaglia G, Akova M, Amicosante G, Cantón R, Cauda R, Docquier J, et al. Metallo- $\beta$-Lactamases as emerging resistance determinants in Gram-negativee pathogens: open issues. Int J Antimicrob Agents 2007; 29:380-388.

2. Walsh TR, Toleman MA, Poirel L, Nordmann P. Metallo- $\beta$-Lactamases: the Quiet before the Storm? Clin Microbiol Rev 2005; 18:306-325.

3. Maragakis LL, Perl TM. Acinetobacter baumannii: epidemiology, antimicrobial resistance, and treatment options. Clin Infect Dis 2008; 46:1254-1263.

4. Picão RC, Andrade SS, Nicoletti AG, Campana EH, Moraes GM, Mendes RE, et al. Metallo- $\beta$-Lactamase detection: comparative evaluation of double-disk synergy versus combined disk tests for IMP-, GIM-, SIM-, SPM-, or VIM-producing isolates. J Clin Microbiol 2008; 46:2028-2037.

5. Zavascki AP, Barth AL, Gonçalves ALS, Moro ALD, Fernandes JF, Martins, AF, et al. The influence of metallo- $\beta$-lactamase production on mortality in nosocomial Pseudomonas aeruginosa infections. J Antimicrob Chemother 2006; 58:387-392.

6. Zarrilli R, Giannouli M, Tomasone F, Triassi M, Tsakris A. Carbapenem resistance in Acinetobacter baumannii: the molecular epidemic features of na emerging problem in health care facilities. J Infect Dev Ctries 2009; 3:335-341.

7. Payne DJ, Bateson JH, Gasson BC, Proctor D, Khushi T, Farmer TH, et al. Inhibition of Metallo- $\beta$-Lactamases by a series of mercaptoacetic acid thiol ester derivatives. Antimicrob Agents Chemother 1997; 1:135-140.

8. Clinical and Laboratory Standards Institute. Methods for dilution antimicrobial susceptibility tests for Bacteria that grow aerobically. Seventh edition: Approved Standard M7-A7. Wayne, PA: Clinical and Laboratory Standards Institute; 2006. 